\section{French journalism defended}

SIR - For the past several months, Nature has made virulent attacks on the behaviour of French judges, police and the press over the so-called "contaminated blood scandal". The mistakes and confusions in the articles Nature has published disregard the elementary verification process that you recommend to researchers.

But a recent Opinion (Nature 373, 546; 1995) insulted us, journalists of the popular press, by comparing us to the tricoteuses of the French Revolution, who revelled in watching the victims being executed.

You accuse us of "exciting the executioners". We are reluctant to believe that the latter term is meant to apply to the judges concerned, whose judgements are based on a precise and well documented file. As for ourselves, we feel that we have fully played our part as a counterweight in a case where medical, political and financial interests intermingle.

Our enquiries have enabled us to shed light on damning and undisputed documents relating to decisions taken between 1983 and 1985 by those in charge of the health system. We chose our words with care and moderation, and our analysis of the errors and faults was always supported by solid arguments. The four people judged in two successive trials were blamed for keeping on the market, in 1985 , products they knew were likely to be contaminated with the AIDS virus, while a calculation made by $\mathrm{Dr}$ Jean-Pierre Allain at the time showed that at least one extra haemophiliac would thus be infected each day as a result. That calculation is still valid today, as four statistical studies later estimated that between 200 and 300 haemophiliacs were contaminated in 1985. We have evidence showing that those decisions were deliberate*.

We have never contended that only four people were involved in this scandal but have argued that other people with medical and administrative responsibility should also answer for their actions before the Court to enable everyone to understand the mechanisms that led to such a failure of our health system. The preliminary enquiries now under way will probably provide an answer to that question. As far as we know, nobody was dragged to the guillotine, as capital punishment was abolished in France in 1981. Your insulting comparison thus turns out to be based on a major historical mistake. As to the analogy between the work of the Paris judges, accomplished in accordance with the basic rules of human rights, and the arbitrary decisions made by the revolutionary juries, the image is inappropriate.

Strangely enough, you fall into line with several transfusion authorities that have been clamouring for an international commission, supposedly above ordinary justice - another insult to democracy. We would be interested to see which independent international experts would back the medical decisions made in 1984-85. Finally, both Britain and France have a history of what may be called the élite approving the worst revisionist theories.

Gérard Badou (L'Express), Béatrice Bantmann (Libération), Hélène Cardin (FranceInter), Anne-Marie Casteret (I'Evénement du jeudi),Guillaume Malaurie (L'Evénement du jeudi), André Mazzolini (Libération), Hélène Moliere (Europe 1), Anne-Pierre Noel (La Cinq), Jean-Luc Nothias (Le Figaro), Françoise Parinaud (RTL), Vincent Olivier (Le Parisien), Michel de Pracontal (Le Nouvel Observateur), Bernard Seytre (journaliste indépendant)

*Letter from J. P. Allain dated 19 January 1985; Memorandum from Dr J. B. Brunet to Professor Roux, head of the DGS (Direction Générale de la Santé: General Health Management), dated 12 March 1985; CNTS internal memoranda in May, June and July 1985; Letter from Dr Garretta to the DGS dated 9 May 1985. Report of the meeting of 29 May 1985 at the CNTS (Centre National de Transfusion Sanguine: National Centre for Blood Transfusion) and so on

\section{Parents' rights}

SIR - John Godfrey has articulated a reasoned concept of the gradual rather than the instantaneous development of the human person. His Commentary (Nature 373, 100; 1995), while written from an independent point of view, is in line with the views of many Roman Catholic doctors. It is important that the issue should not be regarded as being irrevocably closed and that the legitimacy of conflicting views should continue to be tolerated.

In Ireland, many parents of genetically determined handicapped children look for antenatal diagnosis, and some, in the light of their own knowledge and experience, opt for termination. Older parents are frequently angry if they have a Down's syndrome baby without having had the option of antenatal diagnosis. These observations are based on a long experience of clinical practice. Children vary in height, weight and intelligence and we are accustomed to recognizing a wide range of acceptable values. In the same way, parents vary in their endurance, their insight and their coping capacity. An elderly and ascetic priest once defined this clearly to me in terms of the need to respect the limitations of parents. Parents' endowment is in the gift of the Almighty and parents have an inherent right to have their God-given limitations acknowledged and should not be expected to perform beyond the limits of their endowment.

As long as it remains an open question whether the starting point of actual as against potential human development is instantaneous or gradual, parents can still be supported in good faith in whatever difficult decisions they take in relation to abortion. We should not interfere with their right to their limitations.

There has been disquiet among doctors about the consolidation of fixed positions in these matters. In 1983, when a referendum was held in the Republic of Ireland on the amendment of the constitution so as to prohibit legislation on abortion, seven professors of paediatrics publicly expressed their concern. All but one were Roman Catholic.

When parents unburden themselves behind the closed doors of the consulting room they have a right to be heard, and on their own terms. Godfrey restates a basis for one of the options for the ethical decision-making process and so is to be welcomed.

Abortion has been listed as a basis for automatic excommunication in the Roman Catholic church. In the Republic of Ireland the ratio of abortions to deliveries is close to $1: 10$. On this basis there must already be 30,000 excommunicated women in the Republic. By the year 2000 there will be 50,000 . Exclusion of these women from the rites and the formal fellowship of the church turns on the insistence that there is only one answer to the question of the point of inception of human life.

If this issue is not left open, sexually active women of child-bearing age will have to conditionally baptize their menstrual products each month in case the tiny morula of one of the 50-80 per cent of spontaneously aborted two-week-old fetuses should he flushed away unmourned

\section{O. Conor Ward}

University College, Dublin, Ireland

\section{Necessary brain}

SIR - Benjamin Libet suggests (Nature $375,100 ; 1975)$ that "without a functioning brain there is no human person", and then equates the status of an embryo with that of "an adult whose brain is dead" and from whom, incidentally, tissues "may legally be removed for transplantation". Following Libet's argument, one could remove tissues from an embryo (or damage it through discharge of industrial pollutants) without fearing legal action when the embryo grows up - one would never have harmed a "human person" sensu Libet.

\section{Peter Forster}

1 Heinrich-Pette-Institut,

University of Hamburg, Germany

\section{Correspondence}

Letters submitted for Correspondence should be typed, double-spaced, on one side of the paper only. 